AgnieszKa Pach-Gurgul

Uniwersytet Ekonomiczny, Kraków, Polska

\title{
Perspektywy wykorzystania gazu lupkowego w energetyce Unii Europejskiej
}

\section{Prospects of the Use of Shale Gas in the EU Power Sector}

Streszczenie: W dyskusjach na temat międzynarodowych rynków gazu oprócz niepewności związanej ze zmianami popytu na gaz dominuje kwestia jego wydobycia ze złóż niekonwencjonalnych, w tym z łupków. Pozyskanie i wykorzystanie gazu z łupków w Stanach Zjednoczonych istotnie wpłynęło bowiem na gospodarkę tego kraju i spowodowało spadek jego cen, obniżenie kosztów produkcji oraz wzrost konkurencyjności gospodarki i wiele innych efektów określanych mianem „rewolucji łupkowej”. Obecnie w Unii Europejskiej trwa dyskusja nad wykorzystaniem gazu łupkowego w unijnej energetyce. Z jednej strony przytaczane są pozytywne efekty rewolucji łupkowej w Stanach Zjednoczonych i Kanadzie, możliwość zmniejszenia uzależnienia od importu gazu z Rosji a przy tym zwiększenia swojego bezpieczeństwa energetycznego, z drugiej strony przeciwstawiane są potencjalne zagrożenia dla środowiska naturalnego, w tym możliwości zatrucia wód gruntowych.

Artykuł jest próbą znalezienia odpowiedzi na następujące pytania badawcze:

- Czy w krajach Unii Europejskiej o potencjalnych zasobach gazu łupkowego nastąpi jego wykorzystanie i w jakim zakresie?

- Jakie efekty „europejska rewolucja łupkowa” może przynieść dla poszczególnych krajów Unii Europejskiej oraz całego ugrupowania integracyjnego?

- Czy Unia Europejska włączy wykorzystanie gazu łupkowego w reguły wspólnej polityki energetycznej, czy decyzje w tej kwestii podejmować będzie suwerennie każdy kraj?

Wydaje się, iż gaz łupkowy jest również szansą dla unijnej energetyki, jednakże perspektywy jego eksploatacji i wykorzystania zależeć będą przede wszystkim od woli państw członkowskich, ich miksów energetycznych oraz od stanowiska Unii Europejskiej w tej kwestii.

\begin{abstract}
Apart from the uncertainty associated with changes in the demand for gas, the discussion on international gas markets is dominated by the question of gas production from unconventional sources, including shale. Because the acquisition and use of shale gas in the United States had a significant impact on the economy and led to a significant gas prices fall, reduction of production costs and the increase of the economy competitiveness as well as many other effects known as "shale revolution". European Union is currently absorbed by the discussion of shale gas use in the EU energy sector. On the one hand, there are many positive effects of "shale revolution" in the United States and Canada, the exploitation of shale gas can reduce the dependence on gas imports from Russia and increase energy security. But on the other hand, shale gas is indicated as a potential threat to the environment, including the possibility of groundwater contamination.
\end{abstract}


This article is an attempt to find answers to the following questions: - whether the European Union countries possessing potential shale gas resources will decide to explore them and to what extent, - what the potential effects of the "European shale revolution" for the individual countries as well as for the whole European Union are, - what the prospects for shale gas to be included in common energy policy are, or whether decisions in this matter will remain the sovereign responsibility of EU countries?

It seems that shale gas is an opportunity for the EU energy sector; however, its exploitation and usage will depend primarily on attitude of EU members, their energy mixes and the standpoint of the European Union regarding this issue.

Słowa kluczowe: energetyka, polityka energetyczna, bezpieczeństwo energetyczne, gaz konwencjonalny, gaz niekonwencjonalny, gaz łupkowy, szczelinowanie hydrauliczne, „rewolucja łupkowa”

Key words: power sector, energy policy, energy security, conventional gas, unconventional gas, shale gas, hydraulic fracturing, ,shale revolution”

\section{WPROWADZENIE}

Pozyskanie i wykorzystanie gazu z łupków w Stanach Zjednoczonych istotnie wpłynęło na gospodarkę tego kraju. Spowodowało zwiększenie obfitości gazu, a co za tym idzie spadek jego cen, obniżenie kosztów produkcji oraz wzrost konkurencyjności gospodarki i wiele innych efektów określanych mianem „rewolucji łupkowej”. Pomimo, iż efektom tym towarzyszyły określone koszty, wydaje się, iż „rewolucja łupkowa” stała się szansą na rozwiązanie niedoboru tego surowca w krajach posiadających duże potencjalne jego zasoby.

Obecnie w Unii Europejskiej trwa dyskusja nad wykorzystaniem gazu łupkowego w unijnej energetyce. $Z$ jednej strony przytaczane są pozytywne efekty rewolucji łupkowej w Stanach Zjednoczonych i Kandzie, możliwość zmniejszenia uzależnienia od importu gazu z Rosji a przy tym zwiększenia bezpieczeństwa energetycznego krajów UE, z drugiej strony przeciwstawiane są potencjalne zagrożenia dla środowiska naturalnego, w tym możliwości zatrucia wód gruntowych.

\section{EFEKTY „REWOLUCJI ŁUPKOWEJ” w USA}

Obserwując toczącą się debatę nad wykorzystaniem gazu łupkowego w energetyce Unii Europejskiej nie sposób pominąć „,rewolucji łupkowej” i jej efektów w Stanach Zjednoczonych Ameryki Północnej. USA stały się bowiem na świecie pionierem w zakresie pozyskiwania tego surowca przy zastosowaniu unikalnych technologii.

Gaz łupkowy zaczęto wydobywać w USA w XIX w. a pierwszy odwiert miał miejsce w 1821 r. w miejscowości Fredonia w zachodniej części Stanu Nowy Jork. Jednakże prymitywna wówczas technologia oparta na pionowych odwiertach oznaczała, że surowiec dało się pozyskiwać jedynie ze źródeł usytuowanych kilka metrów pod powierzchnią ziemi. Powodowało to wysokie koszty perforacji i eksploatacji gazu łupkowego, co ostatecznie 
wpływało na nieopłacalność jego wydobycia (Instytut Kościuszki 2012: 23). Dopiero w 1997 r. dzięki zastosowaniu tzw. szczelinowania hydraulicznego ${ }^{1}$ oraz nowej technologii poziomych odwiertów ${ }^{2}$, wykonano pierwszą instalację, która uznana została za instalację dochodową (Trembath 2012, 25 stycznia). W wyniku ich zastosowania zainteresowanie gazem łupkowym błyskawicznie wzrosło, a skały łupkowe zaczęły przyciągać inwestorów na teren Stanów Zjednoczonych. Jednakże na efekty rewolucji łupkowej trzeba było jeszcze poczekać.

W 2008 r., podczas gdy amerykańscy gazownicy dopiero rozpoczynali na większą skalę wiercenia w łupkach, ceny gazu na giełdach surowcowych w USA biły rekordy. Za $1000 \mathrm{~m}^{3}$ tego surowca w Nowym Jorku trzeba było zapłacić 480 USD. Dla gospodarki Stanów Zjednoczonych była to trudna sytuacja, gdyż gaz w energetyce tego kraju jest najważniejszym paliwem, determinującym ceny w wielu segmentach gospodarki, a tym samym oddziałuje na jej konkurencyjność. Przykładowo w 2008 r. ze złóż w łupkach pochodziło niewiele ponad 10\% całkowitej produkcji gazu w Stanach (por. ryc. 1). Jednak już w 2009 r. dzięki rewolucji technologicznej (tj. szczelinowaniu hydraulicznemu i technologii poziomych odwiertów) zwiększył się udział gazu z łupków w całkowitej produkcji gazu, a USA stały się największym producentem gazu na świecie wydobywając $582 \mathrm{mld} \mathrm{m}^{3}$ (BP 2012). W $2011 \mathrm{r}$. produkcja gazu osiągnęła aż $651 \mathrm{mld} \mathrm{m}^{3} \mathrm{z}$ czego $175 \mathrm{mld} \mathrm{m}^{3}$ (ponad 26\% całkowitej produkcji gazu) stanowiła jego produkcja ze źródeł niekonwencjonalnych, w tym z gazu z łupków.

Wydobycie gazu z łupków w USA wykazuje tendencję wzrostową a wstępne szacunki wskazują, że na koniec 2012 r. jedną trzecią gazu wydobywanego w USA stanowić będzie gaz łupkowy.

Eksploatacja gazu łupkowego zwiększyła obfitość gazu w USA, obniżając jego cenę z 480 USD za 1000 m³ w 2008 r. do 120-130 USD w 2012 r. Szacuje się, iż dzięki spadkowi cen gazu przeciętne gospodarstwo domowe w USA w 2012 r. zaoszczędzi na rachunkach z gazowni średnio ok. 926 USD (Instytut Kościuszki 2012: 30). Zaoszczędzi również na rachunkach z elektrowni, chociaż ceny energii elektrycznej nie spadły tak gwałtownie jak ceny samego gazu. W latach 2008-2011 ceny energii elektrycznej w USA kształtowały się na dość wysokim poziomie, jednakże od 2011 r. zauważalna jest na rynku tendencja spadkowa, co jest już w pewnym zakresie rezultatem niższych cen gazu, służącego w dużym stopniu do jej wytworzenia (por. ryc. 2).

\footnotetext{
${ }^{1}$ Szczelinowanie hydrauliczne (kruszenie hydrauliczne) - polega na wtłoczeniu do szczelin piasku z wodą o dobranej do porowatości skały granulacji, wciskającego się w pęknięcia i uniemożliwiającego ich zamknięcie, jednocześnie tworzącego naturalne drogi komunikacji dla gazu dopływającego do otworu. Do płynu szczelinującego dodaje się substancje chemiczne wspomagające poprawne wykonanie zabiegu.

2 Technika wiercenia poziomego polega na początkowym odwierceniu pionowego otworu wiertniczego, a następnie, po osiągnięciu odpowiedniej głębokości, skrzywieniu i stopniowym przejściu do odcinka poziomego celem przewiercenia docelowej warstwy skalnej nawet na odległość od jednego do ponad trzech kilometrów od pionowego szybu.
} 


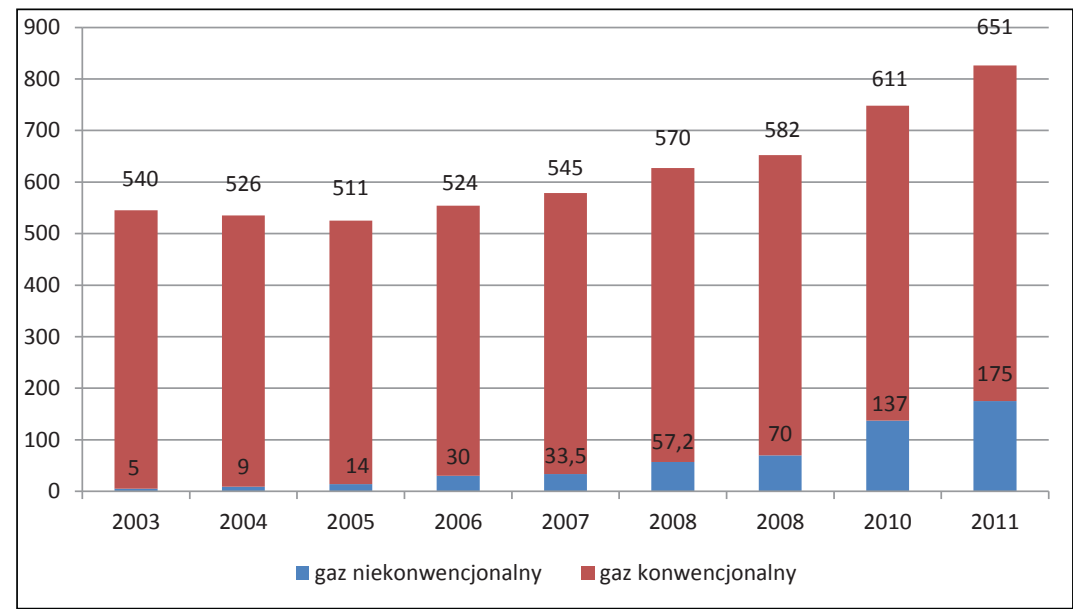

Ryc. 1. Wydobycie gazu konwencjonalnego i niekonwencjonalnego* w USA od 2003 r. (w mld m³)

* gaz ziemny dzieli się zwykle na dwie kategorie: pozyskiwany ze złóż konwencjonalnych i niekonwencjonalnych (gaz łupkowy, gaz zamknięty, metan pokładów węgla, hydraty metanu). Podział ten wynika głównie z innej struktury geologicznej złóż oraz sposobu ich wydobycia. Wydobycie gazu niekonwencjonalnego jest technicznie trudniejsze i droższe, chociażby ze względu na fakt, iż złoża w skałach łupkowych znajdują się dwa razy głębiej niż gazu konwencjonalnego (Nash 2010)

Źródło: opracowanie własne na podstawie BP Statistical Review of World Energy 2012, s. 20-25

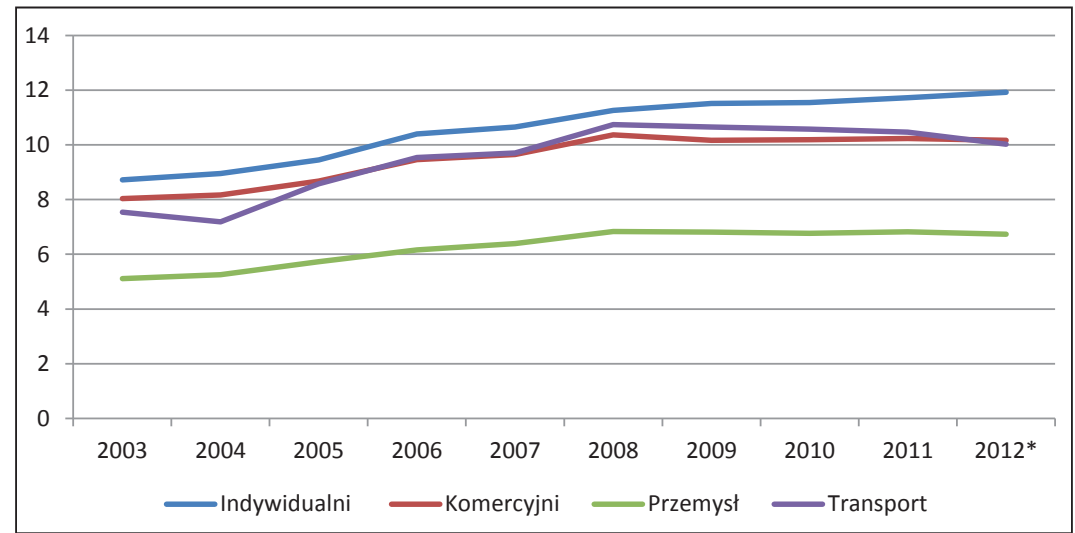

Ryc. 2. Średnie ceny energii elektrycznej dla rynku amerykańskiego w latach 2003-2012 (centy/1kWh)

* ceny energii elektrycznej w 2012 r. wyznaczone są do października

Źródło: opracowanie własne na podstawie danych U.S. Energy Information Administration, http://205.254. 135.7/electricity/monthly/epm_table_grapher.cfm?t=epmt_5_3 (data dostępu: 17.12.2012)

Wpływ rewolucji łupkowej w energetyce USA odczuła cała gospodarka USA. Niskie ceny gazu zmieniły strategię amerykańskich firm chemicznych i metalurgicznych, które dotychczas w walce o utrzymanie swej pozycji rynkowej często przenosiły swą produkcję do 
krajów o niższych kosztach produkcji, zwłaszcza do Chin. Niskie ceny gazu spowodowały wzrost konkurencyjności przedsiębiorstw amerykańskich w stosunku do firm z Europy i Azji. Ponadto w pobliżu złóż gazu z łupków amerykańskie firmy zaczęły planować nowe inwestycje: stalownie i huty aluminium.

Sektor gazu łupkowego wpłynął również na wykreowanie nowych miejsc pracy. Według firmy eksperckiej IHS CERA od 2008 r. w ciągu trzech lat branża gazu łupkowego doprowadziła do utworzenia w USA 600 tys. nowych miejsc pracy. Prognozuje się, iż do 2015 r. powstanie 870 tys. nowych miejsc pracy.

Pozytywnym wpływem rewolucji łupkowej jest również znaczący wzrost dochodów budżetów stanowych i lokalnych z tytułu wydobycia gazu łupkowego. W 2010 roku całkowite wpływy fiskalne w USA wyniosły 18,6 mld USD, natomiast prognozuje się, iż w 2035 r. wyniosą one 57,2 mld USD, a łącznie w latach 2010-2035 ma to być 933 mld USD (HIS Global Inside 2012).

Najbardziej odczuwalnym skutkiem rewolucji łupkowej jest jednak zwiększenie bezpieczeństwa energetycznego USA. Ponad $85 \%$ zużywanego gazu jest wydobywane w kraju - co zmniejsza zależność energetyczną od innych państw. Nowe zasoby gazu hupkowego umożliwiają szybki wzrost podaży surowca ze względu na stosunkowo krótki czas doprowadzenia złoża do eksploatacji. Wpływa to ostatecznie na elastyczność i zdolność reagowania produkcji gazu na zapotrzebowanie rynku oraz stabilność dostaw gazu i energii elektrycznej.

Amerykańska rewolucja łupkowa stała się zachęcającym przykładem dla innych krajów o potencjalnie dużych zasobach gazu z łupków, zwłaszcza Chin, gdzie jeszcze brakuje podstawowej infrastruktury do eksploatacji i transportu gazu z łupków.

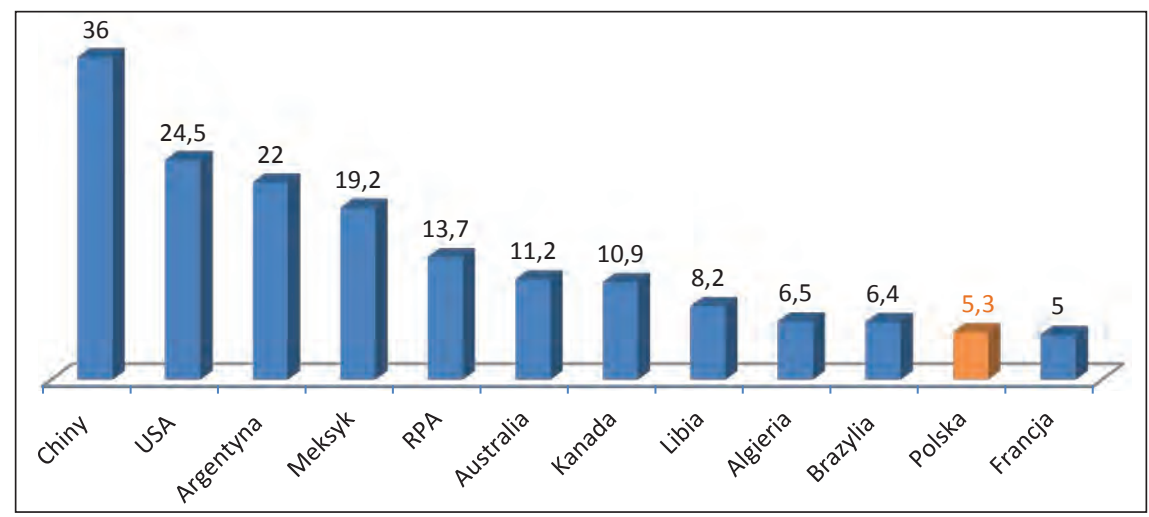

Ryc. 3. Kraje o potencjalnych największych zasobach gazu z łupków według U.S. Energy Information Administration (w bln $\mathrm{m}^{3}$ )

Źródło: opracowanie własne na podstawie danych U.S. Energy Information Administration, http://www.eia. gov/analysis/studies/worldshalegas/pdf/fullreport.pdf (data dostępu: 17.12.2012)

Pozytywne doświadczenia Stanów Zjednoczonych w zakresie pozyskiwania gazu łupkowego stały się silną inspiracją dla krajów Unii Europejskiej, zarówno tych o dużych 
potencjalnych zasobach gazu łupkowego jak Polska³, jak również krajów o znacznie mniejszych zasobach jak Wielka Brytania, Niemcy czy Litwa (por. ryc. 4).

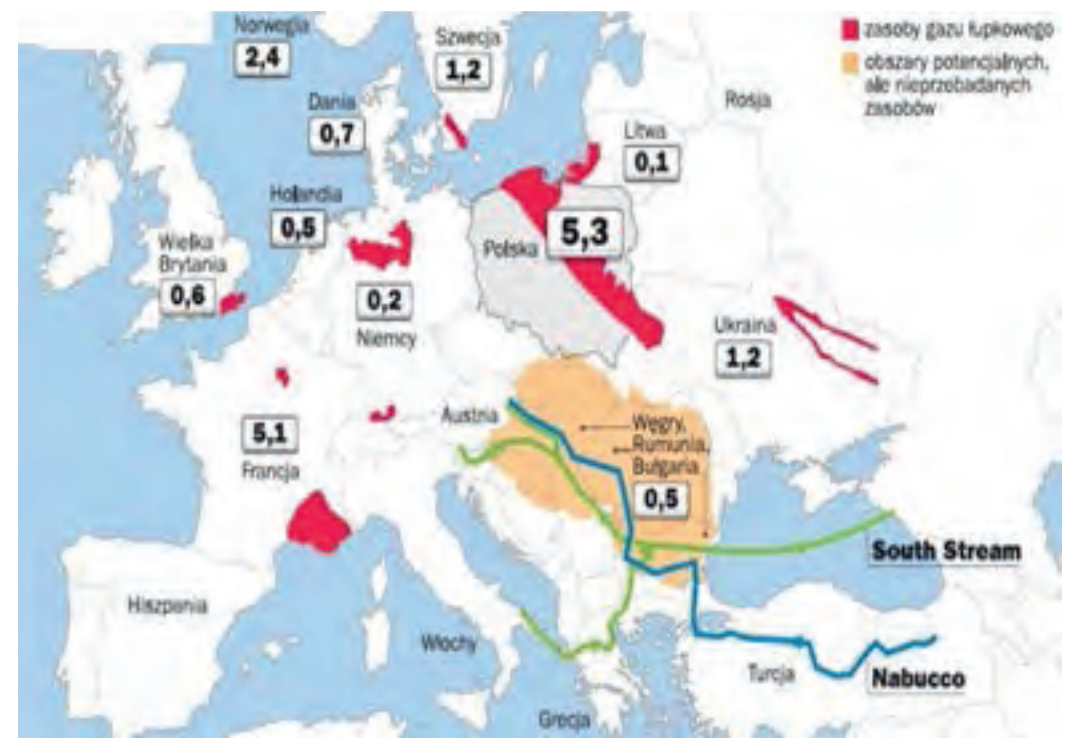

Ryc. 4. Szacunkowe zasoby gazu łupkowego w Unii Europejskiej (w bln $\mathrm{m}^{3}$ )

Źródło: http://wyborcza.biz/biznes/1,100896,11550543,Gaz_lupkowy_Skladniki_plynu_do_szczelinowania _sa.html, przygotowane na podstawie danych Energy Information Administration (data dostępu: 17.12.2012)

Kraje Unii Europejskiej są to kraje o różnych profilach energetycznych i uwarunkowaniach gospodarczych, co istotnie rzutuje na ich stanowiska w kwestii wykorzystania gazu łupkowego w ich energetyce. W tym względzie ważny jest także wymiar ekonomiczny i ekologiczny pozyskiwania gazu z łupków w porównaniu z innymi nośnikami energetycznymi.

\section{ARGUMENTY NA RZECZ WYKORZYSTANIA GAZU ŁUPKOWEGO W ENERGETYCE UNII EUROPEJSKIEJ}

Amerykańskie doświadczenia spowodowały, iż niektóre kraje w Unii Europejskiej dążą do eksploatacji gazu z łupków na dużą skalę. Narastają kontrowersje wokół technologii

${ }^{3}$ Szerzej na temat zasobów węglowodorów w Polsce w: Ocena zasobów wydobywalnych gazu ziemnego $i$ ropy naftowej $w$ formacjach tupkowych dolnego paleozoiku w Polsce (basen bałtycko-podlasko-lubelski). Raport pierwszy, http://www.pgi.gov.pl/en/dokumenty-in/doc_view/771-raport-pl.html (data dostępu: 17.12.2012). 
wydobycia gazu łupkowego i związanej z nią możliwości zatrucia wód gruntowych ${ }^{4}$. Mimo to wydaje się, iż pozyskiwanie gazu łupkowego będzie szansą dla unijnej energetyki w obliczu:

a) Dużego uzależnienia od importowanego gazu, zwłaszcza z Rosji. W 2008 r. Unia Europejska importowała 31,5\% gazu z Rosji (por. ryc. 5). Wprawdzie import ten zmniejszył się w porównaniu z 2000 r., jednakże zależność ta dla niektórych krajów UE jest zdecydowanie większa.

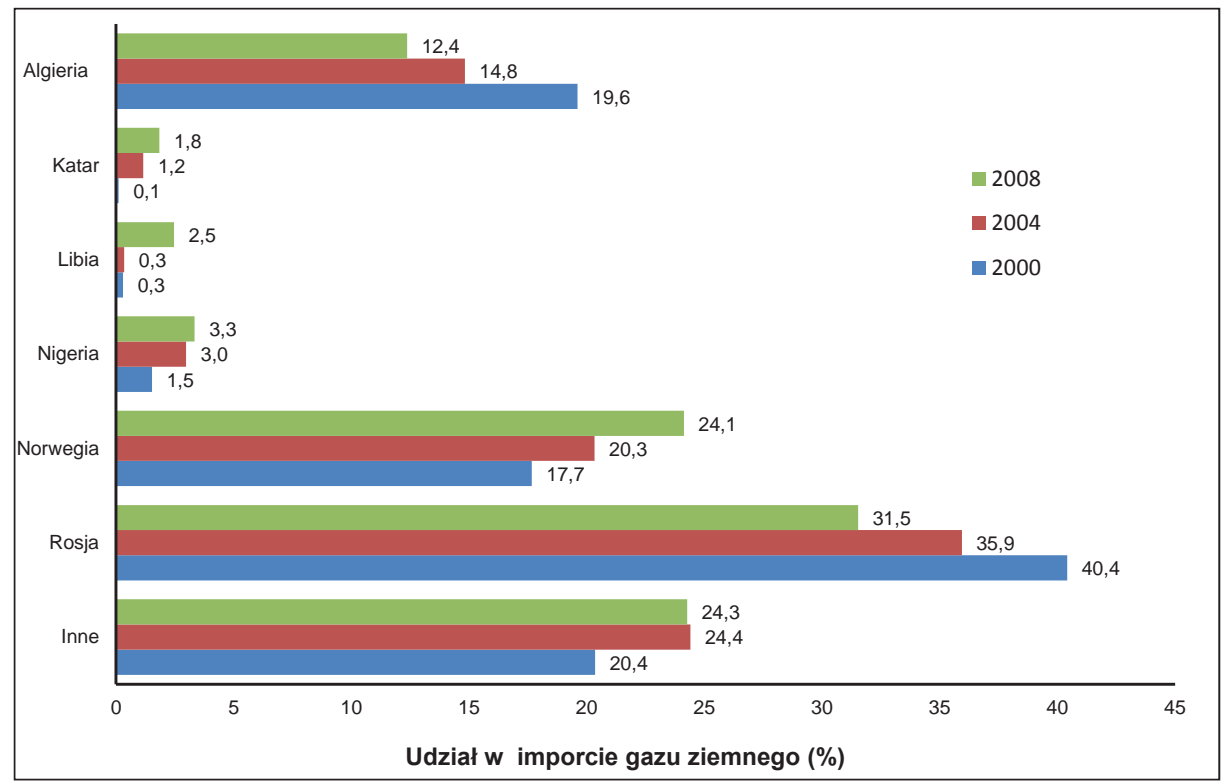

Ryc. 5. Kierunki importu gazu ziemnego przez UE-27 w latach 2000-2008 (w \%)

Źródło: opracowanie własne na podstawie: Energy - Yearly Statistics 2008, Eurostat, European Commission, Publications Office of the European Union, Luxembourg 2010

Do krajów o najwyższym stopniu uzależnienia od rosyjskiego gazu (od 100\% do 60\%) należą: Łotwa, Litwa, Estonia, Finlandia, Słowacja, Bułgaria, Rumunia, Czechy, Węgry, Polska, Grecja, Austria i Słowenia. Są to głównie kraje Europy Środkowo-Wschodniej, w których wysoki udział rosyjskiego gazu w zaspokojeniu całkowitego popytu na gaz został ukształtowany w okresie RWPG (Pach-Gurgul 2012).

b) Kryzysów gazowych - powtarzających się od 2005 r., będących skutkiem konfliktów pomiędzy Rosją a Białorusią i Ukrainą oraz upolitycznienia i zróżnicowania cen gazu dla poszczególnych krajów UE (importerów rosyjskiego gazu). Systematycznie pojawiające się kryzysy gazowe zwiększyły obawy w kwestii nadmiernego uzależnienia od dostaw gazu z Rosji, gdyż np. w wyniku ,przykręcenia przez Rosję kurka Ukrainie” w 2009 r. dostawy

${ }^{4} \mathrm{~W}$ celu wydobycia gazu łupkowego do wydrążonego głęboko pod ziemią poziomego tunelu wtryskuje się pod wielkim ciśnieniem wodę z piaskiem i odrobiną chemikaliów. Skażona woda jest zazwyczaj przechowywana w zbiornikach naziemnych bądź wstrzykiwana z powrotem pod ziemię, a to według ekologów grozi zatruciem wód. 
dzienne gazu z Rosji do UE zmniejszyły się o 60\% a nawet o 90\%. W najtrudniejszej sytuacji znalazły się Bułgaria, Węgry oraz Grecja, do których wstrzymano całkowicie dostawy gazu. Wydarzenia te stały się punktem zwrotnym w polityce energetycznej Unii Europejskiej, zwłaszcza w sprawie bezpieczeństwa energetycznego Wspólnoty.

c) Spełnienia wymogów pakietu energetyczno-klimatycznego, dotyczących $20 \%$ redukcji emisji CO2 do 2020 r. Gaz w UE jest traktowany jako paliwo „pomostowe” pomiędzy wysokoemisyjnym węglem i ropą naftową a odnawialnymi źródłami energii ze względu na relatywnie niską emisję CO2 oraz wysoką kaloryczność. Eksploatacja gazu z łupków na terenie UE mogłaby prowadzić do zwiększenia jego udziału w bilansie energetycznym UE a tym samym do osiągnięcia zamierzonego celu redukcji emisji CO2.

d) Rosnącego popytu na surowce i energię elektryczną w UE. Bazując na wskaźnikach dotychczasowego zużycia energii elektrycznej w UE-27, prognozuje się zwiększenie popytu na energię elektryczną a w konsekwencji na surowce energetyczne. Potwierdza to raport Komisji Europejskiej pt. European Energy and Transport, Trends to 2030 (European Commission, Directorate-General for Energy and Transport 2008). Szacuje się, że w krótkim okresie (tj. do 2030 r.) zużycie energii elektrycznej będzie wzrastać w tempie, w jakim rosło w ostatnich latach. Zakłada się, iż energia elektryczna będzie zaspokajać w 23\% końcowy popyt na całkowitą energię w 2030 r., w porównaniu do 17\% w 1990 r. i 20\% w 2005 r.

e) Wysokich i zróżnicowanych cen energii elektrycznej Unii Europejskiej obniżających jej konkurencyjność międzynarodową. Według raportu „2013 Global Manufacturing Competitiveness Index" (Deloitte Touche Tohmatsu 2012) Niemcy, Francja czy Wielka Brytania, na skutek rosnących kosztów energii elektrycznej będą tracić swoją pozycję na rzecz krajów rozwijających się. Eksploatacja gazu z łupków mogłaby przyczynić się do spadku tych kosztów, podobnie jak w Stanach Zjednoczonych.

f) Przedłużającego się kryzysu gospodarczego. Eksploatacja i wykorzystanie gazu z łupków jest szansą na utworzenie nowych miejsc pracy, obniżkę cen energii elektrycznej dla przemysłu i gospodarstw domowych, poprawę konkurencyjności dla procesu innowacyjności itd., co jest bardzo ważne w czasie wychodzenia z kryzysu gospodarczego, zwłaszcza krajów strefy Euro.

Pomimo tak racjonalnych argumentów, współcześnie w Komisji Europejskiej, Parlamencie Europejskim czy Radzie Europejskiej oraz w krajach członkowskich UE trwa dyskusja na temat wykorzystania gazu łupkowego w unijnej energetyce i włączenia go w ramy wspólnej polityki energetycznej.

\section{STANOWISKO INSTYTUCJI UE ORAZ PAŃSTW CZŁONKOWSKICH} W SPRAWIE GAZU ŁUPKOWEGO

Wydobycie gazu łupkowego stało się tematem dyskusji głównych instytucji unijnych. Kwestia ta bowiem nie była dotychczas przedmiotem wspólnej polityki energetycznej i stąd debata nad włączeniem jej do wspólnej polityki energetycznej lub pozostawieniem jej w gestii państw członkowskich. 
Rada Europejska zainicjowała oficjalnie włączenie problematyki gazu niekonwencjonalnego, w tym łupkowego, do debaty politycznej UE. W lutym 2011 r. odbyło się posiedzenie Rady Europejskiej dotyczące problemów energetycznych. Uzgodniono, iż dalsze wzmacnianie bezpieczeństwa dostaw nośników energii wymaga oceny potencjału Europy w tym zakresie oraz wykorzystania konwencjonalnych i niekonwencjonalnych złóż gazu, w tym gazu łupkowego (Rada Unii Europejskiej 2011: 3).

Z kolei w listopadzie 2010 r. Komisja Europejska przedstawiła strategię energetyczną na lata 2010-2020 (European Commission 2010). Potwierdziła w niej priorytetowe cele: dokończenie budowy jednolitego rynku energii, rozwój połączeń elektroenergetycznych i gazowych, realizację celów polityki klimatycznej. W dokumencie tym Komisja zwróciła uwagę na postęp techniczny i nowe możliwości w zakresie eksploatacji zasobów gazu niekonwencjonalnego, podkreślając opłacalność ekonomiczną jego eksploatacji.

Należy podkreślić, iż niekonwencjonalne zasoby gazu wprowadzają nową zmienną do dotychczas realizowanej i kreowanej przez Komisję Europejską wspólnej polityki energetycznej (Polski Instytut Spraw Międzynarodowych 2011). Z tego powodu na początku dyskusji nad wykorzystaniem gazu łupkowego wyraźnie dominowało podejście asekuracyjne, argumentowane niedostateczną wiedzą na temat zasobów, możliwości technologicznych i ekonomicznej opłacalności wydobywania gazu łupkowego. Od 2010 r. w deklaracjach Komisji zauważyć można zmianę polegającą na silniejszym podkreślaniu roli zasobów niekonwencjonalnych gazu w bilansie energetycznym UE. Jednakże cały czas wydaje się, iż KE boryka się z dylematem czy wspierać rozwój nowego sektora wydobywczego, czy odwołując się do zasady subsydiarności pozostawić to zainteresowanym państwom i skupić się na rozwoju odnawialnych źródeł energii i idei dekarbonizacji? (Polski Instytut Spraw Międzynarodowych 2011).

Wydaje się, iż Komisja Europejska skłania się raczej ku drugiemu podejściu, podkreślając, że finansowanie projektów pilotażowych dotyczących wydobywania gazu łupkowego $\mathrm{z}$ funduszy publicznych jest niewłaściwe. $\mathrm{Z}$ drugiej strony temat jest na tyle ważny, iż Komisja Europejska zadeklarowała, że z początkiem roku 2013 zacznie konsultacje społeczne ws. gazu łupkowego w Europie a w ich efekcie zaproponuje ,ramy zarządzania ryzykiem", co może oznaczać nowe przepisy regulujące wydobycie tego surowca w Unii Europejskiej. Prowadzone za pośrednictwem internetu konsultacje społeczne (we wszystkich językach Unii Europejskiej) mające dotyczyć przyszłego rozwoju w Europie niekonwencjonalnych paliw kopalnych, takich jak gaz łupkowy, zakończą się 20 marca 2013 r. Następnie KE opierając się na analizach prowadzonych od końca 2011 r. zaproponuje „ramy zarządzania ryzykiem”, które mają umożliwić „usunięcie problemów regulacyjnych” i zapewnić maksymalną jasność prawa dotyczącego m.in. gazu łupkowego (KE rozpoczyna konsultacje społeczne w sprawie gazu łupkowego, http://lupkipolskie.pl, 21.12.2012).

Najżywsza dyskusja nad wykorzystaniem gazu łupkowego miała miejsce w Parlamencie Europejskim. W toczącej się w UE debacie o możliwościach eksploatacji gazu łupkowego wyraźnie dominowały kwestie środowiskowe. W lutym 2011 r. na wniosek przedstawicieli frakcji Zielonych na spotkaniu koordynatorów Komisji ds. Ochrony Środowiska Naturalnego, Zdrowia Publicznego i Bezpieczeństwa Żywności podjęto decyzję o zleceniu wykonania 
studium wpływu wydobycia gazu łupkowego i łupków bitumicznych na środowisko naturalne i zdrowie społeczeństwa (European Parliament, Committee on the Environmental, Public Health and Food Safety. Coordinators' meeting, 17.02.2011). Przeprowadzono dyskusję nad raportem dotyczącym wykorzystania gazu łupkowego w kontekście skutków dla środowiska naturalnego. Wprowadzono poprawkę do raportu, mówiącą o zakazie stosowania technologii szczelinowania hydraulicznego na obszarach ochrony wody pitnej i wydobycia węgla kamiennego. Zgłoszona przez frakcję Zielonych poprawka nie była zrozumiała zwłaszcza dla Polski, której energetyka opiera się na węglu i która w pewnym sensie potraktowała ten zapis jako uderzenie w możliwość wydobywania gazu łupkowego na swoim terytorium.

Ostatecznie w dniu 21.11.2012 r. projekt nie został przegłosowany i w związku z tym każde Państwo UE będzie miało prawo samo decydować o eksploatacji łupków pod warunkiem stosowania najwyższych standardów ochrony środowiska i zdrowia ludzi, tzw. ,golden rules" (złotych zasad). Zasady te dotyczą przede wszystkim właściwego wyboru lokalizacji odwiertu i zbadania geologii obszaru, wdrażania solidnych zasad dotyczących projektowania, budowy, cementowania i badania szczelności szybów, stałego monitoringu, ograniczania zużycia wody i środków chemicznych, odpowiednich relacji ze społecznościami lokalnymi (International Energy Agency 2012). Stosowanie ,złotych zasad” może podnieść całkowity koszt typowego szybu dla gazu z łupków o około 7\%, jednak w przypadku większych projektów dodatkowe inwestycje w środki ograniczenia wpływu na środowisko mogą równoważyć niższe koszty operacyjne (International Energy Agency 2012).

Również kraje członkowskie posiadają odmienne stanowiska na temat wykorzystania gazu hupkowego w ich energetyce. Wynika to m.in. z priorytetów ich narodowych polityk energetycznych, tzw. miksów energetycznych, posiadanych zasobów surowców energetycznych i uwarunkowań gospodarczych. W związku z tym zainteresowanie państw członkowskich poszukiwaniami i wydobyciem gazu łupkowego jest różne. Wśród decydujących kryteriów jakimi kierują się państwa członkowskie w dyskusji, znajdują się przede wszystkim kryteria rynkowe (ekonomiczna opłacalność wydobycia), ekologiczne (wpływ na środowisko naturalne) i bezpieczeństwa energetycznego (zmniejszenie zależności dostaw gazu spoza UE).

Według szacunków poszczególnych firm konsultingowych i firm energetycznych to Polska jest w Unii Europejskiej krajem najbardziej obfitym w gaz łupkowy, chociaż szacunki zasobów są różne. Według firmy Wood Mackenzie zasoby te mogą wynosić ok. 1,4 bln $\mathrm{m}^{3}$ a według Advanced Resources International - 3 bln $\mathrm{m}^{3}$, z kolei według Energy Information Administration - 5,3 bln $\mathrm{m}^{3}$, podczas gdy rocznie wykorzystuje się w Polsce ok. $14 \mathrm{mld} \mathrm{m}^{3}$ gazu (Orlen 2010: 43). Jeśli nawet potwierdziłyby się te ostrożniejsze szacunki, to Polska zyskałaby zasoby gazu na ponad 100 lat. Dla Polski jest to nowa alternatywa, jeszcze nie do końca potwierdzona, gdyż trudno jest obecnie rzetelnie zweryfikować te szacunki. Tak naprawdę o wielkości bazy zasobowej przesądzą wyniki realizacji prac wykonywanych w ramach udzielonych koncesji na poszukiwanie i rozpoznawanie złóż gazu łupkowego, wydanych w latach 2007-20105. Potwierdzenie występowania gazu łupkowego i jego ilości

${ }_{5}$ Zakres prac przewidzianych w ramach udzielonych koncesji obejmuje przede wszystkim analizę archiwalnych danych oraz ich interpretację, terenowe badania sejsmiczne oraz wykonywanie wierceń poszukiwawczych i rozpoznawczych. 
powinno nastąpić w ciągu 4 lat, czyli w okresie, na jaki średnio wydano koncesje poszukiwawcze (Pach-Gurgul 2012). Jeżeli szacunki dotyczące zasobów gazu łupkowego okażą się prawdziwe, to w Polsce nastąpi przemodelowanie rynku energetycznego. Polska ma wtedy szansę zmniejszyć swoje uzależnienie od importu drogiego gazu z Rosji, które wynosiło ok. 70\% w 2008 r. (Eurostat, European Commission 2010), obniżyć koszty energii elektrycznej, wykreować nowe miejsca pracy. Dlatego Polska silnie wspiera inicjatywę wykorzystania gazu łupkowego w energetyce na forum Unii Europejskiej, podkreślając przyszłościowe pozytywne skutki pozyskiwania i wykorzystania tego surowca.

Odmienne stanowisko reprezentuje Francja, której energetyka bazuje przede wszystkim na energii z elektrowni atomowych a gaz nie odgrywa istotnej roli w bilansie energetycznym. Pomimo dużych szacowanych zasobów tego surowca (według Energy Information Administration - $5 \mathrm{bln}^{3}$ ) partie ekologiczne wezwały do wprowadzenia zarówno we Francji jak i w całej Unii Europejskiej moratorium na wydobycie gazu łupkowego powołując się na brak uregulowań środowiskowych, społecznych i sanitarnych, nieprzemyślaną akcję promowania przemysłu wydobywczego, niekorzystnie wpływającego na rozwój odnawialnych źródeł energii a także na brak jakiejkolwiek debaty publicznej czy politycznej na ten temat.

Z kolei Niemcy we wrześniu 2010 r. przyjęły strategię energetyczną do roku 2050, w której postanowiono, iż 80\% energii elektrycznej powinno pochodzić z odnawialnych źródeł energii (Polski Instytut Spraw Międzynarodowych 2011). Przez długi czas nie podejmowano w Niemczech kwestii wydobywania gazu łupkowego, gdyż priorytetem stały się ustalenia strategii. Jednak zainteresowanie ewentualnymi zasobami gazu łupkowego przez takie firmy jak Exxon Mobil spowodowały, iż Partia Zielonych w obawie o wpływ ewentualnego wydobycia gazu niekonwencjonalnego na środowisko, w lutym 2011 r. wystosowała otwarty list do kanclerz Angeli Merkel z postulatem zakazu stosowania szczelinowania hydraulicznego. Jednakże w grudniu 2012 r. niemiecki parlament zdecydował, że nie wprowadzi, tak jak Francja, zakazu szczelinowania hydraulicznego. Koalicja rządząca odrzuciła regulacje przygotowane przez Partię Zielonych uzasadniając, iż nie ma powodu, żeby zakazać w Niemczech technologii, która jest wykorzystywana wiele lat bez żadnych wypadków (Niemiecki Parlament odrzucit zakaz szczelinowania hydraulicznego, http://www. lupkipolskie.pl, 14.12.2012).

W Wielkiej Brytanii, w przeciwieństwie do Francji, gaz odgrywa istotną rolę w bilansie energetycznym. W ostatnich latach z powodu kurczących się zasobów Wielka Brytania stała się importerem gazu, który przede wszystkim kupuje od Holandii i Norwegii. Mimo zachowawczego stanowiska władze brytyjskie od 2010 r. coraz bardziej interesują się możliwościami eksploatacji gazu łupkowego. W 2010 r. pojawiły się pierwsze publikacje dotyczące eksploatacji gazu łupkowego w kontekście realizowanej polityki energetycznej Wielkiej Brytanii, którego zasoby amerykańska EIA oszacowała na ok. 0,6 bln $\mathrm{m}^{3}$. W przygotowanych analizach z jednej strony zostały podkreślone pozytywne efekty rewolucji łupkowej w USA, z drugiej zaś przebija się sceptycyzm co do możliwości powtórzenia amerykańskiego sukcesu w państwach europejskich (Polski Instytut Spraw Międzynarodowych 2011).

Jednakże, gdy w kwietniu i maju 2011 r. podczas wierceń brytyjskiej firmy Cuadrilla Resources zanotowano wstrząsy 1,5 oraz 2,3 stopnia w skali Richtera, postanowiono 
wstrzymać prace, a władze brytyjskie wydały zakaz wydobywania gazu łupkowego. Po długich analizach władze brytyjskie w grudniu 2012 r. ogłosiły, iż znoszą zakaz, ale wydobycie będzie się odbywać pod surową kontrolą, by uniknąć ryzyka aktywności sejsmicznej. Uznano, iż gaz łupkowy to perspektywiczny surowiec i pozwoli krajowi obniżyć zależność od importu surowców energetycznych, a tym samym powinien zostać włączony do bilansu energetycznego Wielkiej Brytanii (Rzad w Londynie zniósł zakaz wydobycia gazu łupkowego metodą szczelinowania, http://www. lupkipolskie.pl/, 13.12.2012).

W Holandii, która jest głównym unijnym producentem i eksporterem gazu rozważa się również eksploatację gazu z łupków. Państwo w ramach własnych badań prowadzi rozpoznanie potencjału gazu niekonwencjonalnego. Doradzająca holenderskiemu rządowi Rada ds. Energii, w lutym 2011 r. bardzo przychylnie ustosunkowała się do wydobycia gazu ze złóż niekonwencjonalnych, w tym z łupków i przedstawiła władzom rozwiązania mające ułatwić eksploatację gazu z łupków (Beckman 2011). W celu zyskania poparcia społecznego zaleciła zagwarantowanie odpowiednich korzyści finansowych właścicielom terenów udostępnionych pod prace eksploatacyjne i wydobywcze (Polski Instytut Spraw Międzynarodowych 2011).

Natomiast kraje skandynawskie, w których zlokalizowane są złoża gazu łupkowego nie są obecnie zainteresowane pozyskiwaniem tego surowca. Dania, która jest jednym z głównych eksporterów gazu w Unii Europejskiej w obliczu kurczenia się zasobów na Morzu Północnym przyjęła strategię tworzenia gospodarki wolnej od węglowodorów. Dlatego w Danii nie ma praktycznie debaty o gazie łupkowym. Podobne stanowisko reprezentuje Szwecja, w której w bilansie energetycznym gaz odgrywa marginalną rolę. Kraj ten również opowiada się za odejściem od węglowodorów na rzecz zwiększenia udziału energii z odnawialnych źródeł i energii jądrowej.

W Rumunii władze na początku były zdecydowanie negatywnie nastawione do poszukiwania i wydobywania gazu łupkowego, pomimo posiadanych złóż i bardzo wysokiego uzależnienia od importu gazu z Rosji, wynoszącego ok. 97\% (Eurostat, European Commission 2010). Na poszukiwanie i wydobycie gazu wprowadzono moratorium. Zdecydowano jednak, że głos w tej sprawie zostanie ostatecznie udzielony mieszkańcom. Głosując w wyborach parlamentarnych w grudniu mieszkańcy Rumunii mieli w referendum odpowiedzieć na pytanie: ,,czy zgadzasz się na ryzyko, że zasoby wody i turystyka zostaną dotknięte przez eksploatację gazu z łupków w południowej części wybrzeża?"(Rumunia zmieni zdanie w sprawie tupków, http://lupkipolskie.pl, 21.12.2012). Sama konstrukcja pytania sugerowała negatywną odpowiedź. Ponadto nieoficjalne założenia przeprowadzonego referendum były takie, iż jego wyniki nie będą wiążące w przypadku zgody mieszkańców kraju na eksploatację łupkowych złóż, a wiążące jeśli ogólny wynik będzie negatywny. Było to rozwiązanie polityczne na wypadek zwycięstwa partii negujących wykorzystanie gazu łupkowego. To wskazuje na upolitycznienie w Rumunii, jak i w wielu innych krajach problemu gazu łupkowego. Decyzje o jego eksploatacji wiążą się często z konkretną opcją polityczną. Po wyborach premier Victor Ponta stwierdził, iż przyspieszenie negocjacji w sprawie rozpoczęcia wydobycia gazu ziemnego z łupków na terenie Rumunii będzie priorytetem rządu.

Z kolei w Bułgarii i w Czechach na poszukiwanie i wydobywanie gazu łupkowego wydano moratorium, co związane jest z opcją polityczną rządów w tych krajach. Być może 
stanowiska tych krajów podlegać będą ewolucji pod wpływem czynników politycznych i ekonomicznych, jak również doświadczeń krajów Unii Europejskiej.

\section{ZAKOŃCZENIE}

Podsumowując powyższe rozważania należy stwierdzić, iż przeniesienie doświadczeń amerykańskich w zakresie wykorzystania gazu łupkowego w energetyce na grunt krajów w Unii Europejskiej determinowane jest splotem różnorodnych czynników, do których zaliczyć należy przede wszystkim:

- Opłacalność ekonomiczną, determinowaną wielkością i kosztami wydobycia, warunkami geologicznymi usytuowania zasobów gazu w łupkach, kosztami koncesji i opłatami eksploatacyjnymi,

- Dostępność i koszty technologii, którą posiadają przede wszystkim firmy amerykańskie zajmujące się od lat pozyskiwaniem gazu z łupków,

- Aspekty ekologiczne, przede wszystkim stosowanie w praktyce przez firmy wydobywające gaz łupkowy tzw. ,złotych zasad” dotyczących m.in.: wyboru lokalizacji odwiertu, zbadania geologii obszaru, badania szczelności szybów, stałego monitoringu środowiska naturalnego wokół odwiertu, ograniczania zużycia wody i środków chemicznych,

- Czynniki polityczne, przekładające się na rządowe przyzwolenie i wsparcie rozwoju sektora gazu łupkowego, bądź na stosowanie zakazów lub innych ograniczeń w tym względzie. Warunkują one regulacje prawne dla firm działających w sektorze gazowym. Ważną rolę odgrywa siła polityczna partii i ugrupowań ekologicznych.

Wydaje się, iż gaz łupkowy jest szansą dla unijnej energetyki, gdyż może zmniejszyć zależność od importu gazu konwencjonalnego z Rosji, zwiększyć bezpieczeństwo energetyczne krajów Unii Europejskiej oraz innowacyjność sektora gazowego, obniżyć koszty energii elektrycznej, zwiększyć konkurencyjność towarów europejskich oraz wykreować nowe miejsca pracy w sektorze. Efekty te zależeć będą w krajach Unii Europejskiej przede wszystkim od:

- Stanowisk państw członkowskich (podejście do gazu łupkowego w krajach o potencjalnych jego zasobach jest bardzo zróżnicowane), ich miksów energetycznych i determinacji włączenia gazu łupkowego do krajowego bilansu energetycznego,

- Stanowiska instytucji Unii Europejskiej w sprawie poszukiwania i eksploatacji gazu łupkowego. Ponadto w Unii Europejskiej trwa debata nad włączeniem tej kwestii do wspólnej polityki energetycznej lub pozostawieniem jej w gestii państw członkowskich, a to rzutować będzie na regulacje prawne dotyczące wydobycia gazu na terenie Unii Europejskiej i jego finansowania. 


\section{Literatura / References}

Beckman, K. (2011). European Energy Review. Dutch Energy Council embraces unconventional gas, 09.02.2011 r.

BP (2012). BP Statistical Review of World Energy 2012.

European Commission, Directorate-General for Energy and Transport (2008). European Energy and Transport, Trends to 2030 - update 2007. Office for Official Publications of the European Communities, Luxembourg.

European Commission (2010). Energy 2020. A strategy for competitive, sustainable and secure energy. Communication from the Commission to the European Parliament, the Council, the European Social and Economic Committee and the Committee of the Regions, COM (2010) 639 final, Brussels.

Eurostat, European Commission (2010). Energy - Yearly Statistics 2008. Publications Office of the European Union, Luxembourg.

HIS Global Inside (2012). The Economic and Employment Contributions of Unconventional Gas Development in State Economies.

International Energy Agency (2012). Golden rules for a Golden Ages of Gas. World Energy Outlook Special Report on Unconventional Gas, International Energy Agency.

Instytut Kościuszki (2012). Wpływ wydobycia gazu tupkowego na rozwój społeczno-ekonomiczny regionów - amerykańskie success story i potencjalne szanse dla Polski. Kraków.

Nash, K. (2010). Shale Gas Development. Nova Science Pub Inc.

Orlen (2010). Gaz Łupkowy. Podstawowe informacje. Warszawa.

Pach-Gurgul, A. (2012). Jednolity rynek energii elektrycznej w Unii Europejskiej w kontekście bezpieczeństwa energetycznego Polski. Warszawa: Wydawnictwo Difin.

Polski Instytut Spraw Międzynarodowych (2011). Gaz łupkowy - szanse i wyzwania dla Polski i Unii Europejskiej w świetle doświadczeń amerykańskich i rozwoju międzynarodowego rynku gazu. Warszawa.

Rada Unii Europejskiej (2011). Konkluzje Rady Unii Europejskiej z 4 lutego 2011 r. EUCO 2/11.

\section{Strony internetowe}

European Parliament, Committee on the Environmental, Public Health and Food Safety.

Coordinators' meeting, 17.02.2011 r. (2012, 17 grudnia). Pozyskano z: http://www.europarl.europa.eu/ document/activities/cont/201102/20110218ATT13929/20110218ATT13929EN.pdf.

KE rozpoczyna konsultacje społeczne w prawie gazu łupkowego (2012, 21 grudnia). Pozyskano z: http://lupkipolskie.pl/aktualnosci/newsy-ze-swiata/12-2012/ke-rozpoczyna-konsultacje-spoleczne-ws-gazu-lupkowego.

Niemiecki Parlament odrzucił zakaz szczelinowania hydraulicznego (2012, 14 grudnia). Pozyskano z: http://www.lupkipolskie.pl/aktualnosci/newsy-ze-swiata/12-2012/niemiecki-parlament-odrzucil-zakaz-szczelinowania-hydraulicznego.

Ocena zasobów wydobywalnych gazu ziemnego i ropy naftowej w formacjach tupkowych dolnego paleozoiku w Polsce (basen battycko-podlasko-lubelski). Raport pierwszy.

(2012, 17 grudnia). Pozyskano z: http://www.pgi.gov.pl/en/dokumenty-in/doc_view/771-raport-pl.html. 
Rumunia zmieni zdanie w sprawie tupków (2012, 27 grudnia). Pozyskano z: http://lupkipolskie.pl/aktualnosci/newsy-ze-swiata/12-2012/rumunia-zmieni-zdanie-w-sprawie-lupkow.

Rząd w Londynie znióst zakaz wydobycia gazu tupkowego metoda szczelinowania (2012, 13 grudnia). Pozyskano z: http://www.lupkipolskie.pl/aktualnosci/newsy-ze-swiata/12-2012/rzad-w-londynie-zniosl-zakaz-wydobycia-gazu-lupkowego-metoda-szczelinowania.

Trembath, A. CNN Blows Obama SOTU Shale Gas Fact-Check (2012, 25 stycznia). Pozyskano z: http:// thebreakthrough.org/blog/2012/01/cnn_blows_obama_sotu_shale_gas.html.

(2012, 17 grudnia). Pozyskano z: http://205.254.135.7/electricity/monthly/epm_table_grapher.cfm?t=epmt_5_3.

(2012,17 grudnia).Pozyskanoz:http://wyborcza.biz/biznes/1,100896,11550543,Gaz_lupkowy_Skladniki_plynu_do_szczelinowania_sa.html, przygotowane na podstawie danych Energy Information Administration.

Agnieszka Pach-Gurgul, dr, Uniwersytet Ekonomiczny w Krakowie, Katedra Międzynarodowych Stosunków Gospodarczych.

Doktor nauk ekonomicznych, adiunkt w Katedrze Międzynarodowych Stosunków Gospodarczych w Uniwersytecie Ekonomicznym w Krakowie. Autorka książki Jednolity rynek energii elektrycznej $w$ Unii Europejskiej w kontekście bezpieczeństwa energetycznego Polski i rozdziałów w książkach o tematyce międzynarodowych stosunków gospodarczych oraz wielu naukowych artykułów dotyczących przede wszystkim: przemian w polskiej i światowej energetyce, bezpieczeństwa energetycznego, wspólnotowej (unijnej) polityki energetycznej, procesu tworzenia jednolitego rynku energii oraz wyzwań ekologicznych dla współczesnej energetyki.

Agnieszka Pach-Gurgul, Ph.D. in Economics, Senior Lecturer in the Department of International Economic Relations at the University of Economics in Cracow. The author of Single Electricity Market in the European Union in the Context of Polish Energy Security as well as many scientific articles and chapters of books relating to the changes in Polish and global power sector, energy security, European Union energy policy, the single energy market and the ecological challenges for the contemporary energy sector.

adres/address: Uniwersytet Ekonomiczny w Krakowie Katedra Międzynarodowych Stosunków Gospodarczych

ul. Rakowicka 27, 31-510 Kraków, Polska

e-mail: apach@uek.krakow.pl 